\title{
Diversity of hyphomycetes on submerged leaf litter in two Atlantic Forest areas in the Northeast of Brazil with comments on the water quality
}

\author{
Diversidade de hifomicetos em folhedo submerso em duas áreas de Mata Atlântica no \\ nordeste do Brasil com comentários sobre a qualidade da água
}

\author{
Elder George Rodrigues do Nascimento ${ }^{1}$ (D), Marcela Alves Barbosa ${ }^{1}$ (D), \\ Wanderson Luiz Tavares ${ }^{1}$ (D) and Elaine Malosso ${ }^{1,2 *}$ (D)
}

\begin{abstract}
'Programa de Pós-graduação em Biologia de Fungos, Universidade Federal de Pernambuco - UFPE, Avenida da Engenharia, s/n, Cidade Universitária, CEP 50740-600, Recife, PE, Brasil

${ }^{2}$ Departamento de Micologia, Centro de Biociências, Universidade Federal de Pernambuco UFPE, Avenida da Engenharia, s/n, Cidade Universitária, CEP 50740-600, Recife, PE, Brasil *e-mail: elaine.malosso@ufpe.br
\end{abstract}

Cite as: Nascimento, E.G.R. et al. Diversity of hyphomycetes on submerged leaf litter in two Atlantic Forest areas in the Northeast of Brazil with comments on the water quality. Acta Limnologica Brasiliensia, 2021, vol. 33, e30.

\begin{abstract}
Aim: The Atlantic Forest is a Brazilian biome whose biota plays a fundamental role in the preservation of water quality. Hyphomycetes play an important role in aquatic ecosystems as they can decompose organic matter and, consequently, contribute to nutrient cycling, maintaining aquatic life. The aim of this work was to determine the diversity and composition of the aquatic hyphomycetes community in two areas of Atlantic Forest in the state of Pernambuco (Charles Darwin Ecological Refuge) and Alagoas (Pedra Talhada Biological Reserve), in addition to comparing these communities with the water abiotic factors. Methods: For this, four collections of submerged decomposing leaves, for evaluation of the fungi community, and water for measuring the parameters: acidity, alkalinity, chlorides, electrical conductivity, total coliforms, color, $\mathrm{BOD}, \mathrm{COD}, \mathrm{DO}$, total nitrogen, $\mathrm{pH}$, total solids, sulfates, temperature and turbidity, and calculation of the Water Quality Index (WQI) were carried out. The samplings took place between July/2018 and May/2019, at six points along a stream in each study area. Results: Fifty-three taxa were identified, and 1926 occurrences were recorded in 2592 leaf fragments. There was a predominance of Blodgettia aquatica, Blodgettia indica, Flagellospora penicillioides, Flagellospora sp., Mycoleptodiscus disciformis, Triscelophorus monosporus and Xylomyces acerosisporus, with similarity of these and other species between the studied areas. In the rainy season, there was a greater occurrence of aquatic hyphomycetes in both areas; however, the diversity of fungi was greater in the Charles Darwin Refuge. Abiotic factors such as temperature, DO and rainfall influence the occurrence of hyphomycetes, however, no community structure was detected or strongly correlated with the studied abiotic variables. Conclusions: The areas presented adequate values for the variables indicative of water quality and high richness of hyphomycetes species, demonstrating the importance of legal protection for the conservation of natural areas.
\end{abstract}

Keywords: Ascomycota; conidial fungi; aquatic ecosystems; water quality.

Resumo: Objetivo: A Mata Atlântica é um bioma brasileiro cuja biota desempenha um papel 
fundamental na preservaçáo da qualidade da água. Os hifomicetos têm um papel importante nos ecossistemas aquáticos, pois são capazes de decompor a matéria orgânica e, consequentemente, contribuem com a ciclagem de nutrientes, mantendo a vida aquática. O objetivo deste trabalho foi determinar a diversidade e composição da comunidade de hifomicetos aquáticos em duas áreas de Mata Atlântica no estado de Pernambuco (Refúgio Ecológico de Charles Darwin) e Alagoas (Reserva Biológica de Pedra Talhada), além de comparar essas comunidades com os fatores abióticos da água. Métodos: Para isso, foram realizadas quatro coletas de folhas submersas em decomposiçáo, para avaliação da comunidade de fungos, e água para aferição dos parâmetros: acidez, alcalinidade, cloretos, condutividade elétrica, coliformes totais, cor, $\mathrm{DBO}, \mathrm{DQO}, \mathrm{OD}$, nitrogênio total, $\mathrm{pH}$, sólidos totais, sulfatos, temperatura e turbidez, e cálculo do Índice de Qualidade da Água (IQA). As coletas foram realizadas entre julho/2018 e maio/2019, em seis pontos ao longo de um riacho em cada área de estudo. Resultados: Foram identificados 53 táxons e registradas 1926 ocorrências em 2592 fragmentos foliares. Houve predomínio de Blodgettia aquatica, Blodgettia indica, Flagellospora penicillioides, Flagellospora sp., Mycoleptodiscus disciformis, Triscelophorus monosporus e Xylomyces acerosisporus, havendo similaridade dessas e de outras espécies entres as áreas estudadas. No período chuvoso houve maior ocorrência de hifomicetos aquáticos nas duas áreas, porém, a diversidade de fungos foi maior no Refúgio Charles Darwin. Fatores abióticos como temperatura, OD e pluviosidade influenciam na ocorrência de hifomicetos, no entanto, nenhuma estrutura de comunidade foi detectada ou fortemente correlacionada com as variáveis abióticas estudadas. Conclusóes: As áreas apresentaram valores adequados para as variáveis indicativas da qualidade da água e alta riqueza de espécies de hifomicetos, demonstrando a importância da proteção legal para conservação de áreas naturais.

Palavras-chave: Ascomycota; fungos conidiais; ecossistemas aquáticos; qualidade da água.

\section{Introduction}

Aquatic fungi can be defined as those that have their life cycle completely adapted to the aquatic environment, including sporulation on submerged substrates (Shearer et al., 2007). Aquatic hyphomycetes are polyphyletic (Belliveau \& Bärlocher, 2005), which means that they do not have a common ancestor to all species. They are found on decomposing leaves and other vegetal substrates submerged in water bodies worldwide (Medeiros et al., 2009). This diversity of habitats promotes a great diversity of species that can be detected and isolated from these environments.

The hyphomycetes represent the asexual stage of the ascomycetes or basidiomycetes and form spores of mitotic origin named conidia, besides conidiophores simple or aggregate in synnema or sporodochium (Seifert et al., 2011). Aquatic hyphomycetes are divided into four groups according to morphology and lifestyle: ingoldian fungi, aero-aquatic fungi, terrestrial-aquatic fungi and facultative aquatic fungi (Goh \& Hyde, 1996; Ittner et al., 2018) which represents a significant diversity in terms of evolution and taxonomy. The main environments in which these fungi inhabit are streams, creeks and rivers, with or without waterfalls (Ingold, 1975). They can also be found in lakes, ponds, and dams (Schoenlein-Crusius et al., 2009), either preserved or impacted by human activities. In these sites, the aquatic fungi colonize substrates such as leaves and twigs where they produce their conidia that will be dispersed by the water or captured in naturally formed foam in the stream (Suresha et al., 2013).

Aquatic hyphomycetes frequently occur in lotic well aerated environments and are among the few fungal groups whose species can, in many cases, be identified based only on the observation of conidia (Descals, 2005; Fiuza et al., 2017), although this can also cause some confusion due to convergence to hydrodynamic forms. Conidia of the hyphomycetes present morphological adaptation for dispersion in the aquatic environment as they are typically branched or sigmoid, and accumulate easily in foams on the water surface (Ingold, 1966). Some species can also be found with lower frequency in lentic or non-aquatic environments (Descals \& Moralejo, 2001).

In Brazil, there have been several studies on aquatic hyphomycetes in the state of São Paulo (Schoenlein-Crusius \& Milanez, 1989; SchoenleinCrusius \& Grandi, 2003; Moreira \& SchoenleinCrusius, 2012; Schoenlein-Crusius et al., 2009, 2016, 2018), especially in the Atlantic Forest. In the Northeast of Brazil, the studies on the hyphomycetes from aquatic environments were carried out mainly in the biome Caatinga (Almeida et al., 2011, 2012; Barbosa et al., 2008; Fiuza \& Gusmão, 2013) and the Atlantic Forest of Pernambuco (Cavalcanti \& Milanez, 2007; Oliveira, 2016; Silva et al., 2019).

Water scarcity, caused particularly by the elevated degree of pollution due to human activities (Gardner, 2002), represents a growing environmental concern for human population. Aquatic hyphomycetes 
are important for the decomposition of organic matter and nutrient cycling in aquatic ecosystems (Fiuza et al., 2017) and they depend on the water to carry out their metabolic activities and reproduction (Descals \& Moralejo, 2001).

Although some efforts have been carried out, studies on the diversity of aquatic hyphomycetes in water bodies of the Northeast region of Brazil are as yet scarce. These fungi play an important role in the decomposition process and in the food web of aquatic ecosystems because, besides being the main decomposers, they improve substrate palatability (Suberkropp, 1992; Cheng et al., 1997; Duarte et al., 2006), promoting its consumption by detritivores. Thus, the aims of this study were to expand the knowledge about diversity and community structure of aquatic hyphomycetes, to provide data for characterization of water quality in two sites of the Atlantic Forest of the Northeast Brazil, and correlate these variables to the occurrence and diversity of hyphomycetes in the studied areas.

\section{Material and Methods}

\subsection{Study areas}

Two areas in the region of the Atlantic Forest of the northeast of Brazil were selected for this study. The Biological Reserve Pedra Talhada (REBIO PT) was created in 1989 (Decree No 98524, from December $13^{\text {th }} 1989$ ) with an area of $4,382.37$ hectares, and it is one of the most important fragments of Atlantic Forest in the region. It is located between the states of Pernambuco (Lagoa do Ouro) and Alagoas (Quebrângulo), with the latter holding the largest area $(92 \%$ of the reserve, Guimarães et al., 2014). This is a region characterized by a tropical rainy climate with two well-defined seasons: dry summer (October to April) and rainy winter (May to September), with annual average of rain between 1,250 and 1,500 $\mathrm{mm}$, and annual average temperature around 25 ${ }^{\circ} \mathrm{C}$ (Guimarães et al., 2014). Despite being a small conservation unit, this REBIO with altitude varying between 459 and 883 m.a.s.l. holds a great diversity of plants, animals, and fungi. The region has a rich hydrographic network with about 180 springs feeding a series of small rivers and streams, mostly perennial (Brasil, 2006), that facilitate aquatic hyphomycetes conidia dissemination.

The Charles Darwin Ecological Refuge (CD Refuge) is a private non-profit reserve, created in the mid-1950s, with the objective of guaranteeing a resting and breeding area for native species in the region. It is located in an area of 60 hectares of Atlantic Forest, in the municipality of Igarassu, Pernambuco, $34 \mathrm{~km}$ from Recife (Magalhães, 2015). The main characteristic of the area is its highly preserved forest intersected by the Tabatinga River, with clear waters on this stretch. It also has an exuberant fauna and flora, which makes the place conducive to educational practices and scientific investigations (Santiago \& Barros, 2003). The CD Refuge has a hot and humid tropical climate with autumn/winter rains. Current average temperature of $25^{\circ} \mathrm{C}$, average annual rainfall of $2000 \mathrm{~mm}$ (Santiago \& Barros, 2003) and the altitude does not rise above 50 m.a.s.l. in the region of the sampling points.

In the study areas, six sampling points were determined on one of the banks of a watercourse, referenced by GPS (Table 1) and the search area for biological material consisted of $1 \mathrm{~m}$ upstream and $1 \mathrm{~m}$ downstream of the reference point. The sampling points were located along the margin and maintaining the minimum distance of $60 \mathrm{~m}$ between them. The sampling site at REBIO PT was considered natural because it is difficult to access and protected by legislation. At the CD Refuge, one point was considered impacted due to the proximity to the highway that gives access to the site. Four collections of water and submerged leaf litter were carried out from July/2018 to May/2019.

\subsection{Leaf litter sampling, processing and analysis}

Submerged leaf litter was collected manually and with the aid of a long-hand sieve, placed in

Table 1. Geographic coordinates of the sampling points in the study sites.

\begin{tabular}{|c|c|c|c|c|}
\hline \multirow{2}{*}{ Sampling points } & \multicolumn{2}{|c|}{ Charles Darwin Refuge } & \multicolumn{2}{|c|}{ Biological Reserve Pedra Talhada } \\
\hline & Lat & Long & Lat & Long \\
\hline 1 & $07^{\circ} 48^{\prime} 58.8^{\prime \prime} \mathrm{S}$ & $034^{\circ} 57^{\prime} 20.2^{\prime \prime} \mathrm{W}$ & $09^{\circ} 14^{\prime} 44.3^{\prime \prime} \mathrm{S}$ & $036^{\circ} 25^{\prime} 12.3^{\prime \prime} \mathrm{W}$ \\
\hline 2 & $07^{\circ} 48^{\prime} 57.0^{\prime \prime} \mathrm{S}$ & $034^{\circ} 57^{\prime} 19.1^{\prime \prime} \mathrm{W}$ & $09^{\circ} 14^{\prime} 44.6 " \mathrm{~S}$ & $036^{\circ} 25^{\prime} 13.2^{\prime \prime} \mathrm{W}$ \\
\hline 3 & $07^{\circ} 48^{\prime} 55.8^{\prime \prime} \mathrm{S}$ & $034^{\circ} 57^{\prime} 18.3^{\prime \prime} \mathrm{W}$ & $09^{\circ} 14^{\prime} 44.6$ " S & $036^{\circ} 25^{\prime} 14.5^{\prime \prime} \mathrm{W}$ \\
\hline 4 & $07^{\circ} 48^{\prime} 53.1^{\prime \prime} \mathrm{S}$ & $034^{\circ} 57^{\prime} 17.6^{\prime \prime} \mathrm{W}$ & $09^{\circ} 14^{\prime} 45.5^{\prime \prime} \mathrm{S}$ & $036^{\circ} 25^{\prime} 14.4^{\prime \prime} \mathrm{W}$ \\
\hline 5 & $07^{\circ} 48^{\prime} 49.7^{\prime \prime} \mathrm{S}$ & $034^{\circ} 57^{\prime} 17.0 ” \mathrm{~W}$ & $09^{\circ} 14^{\prime} 45.9^{\prime \prime} \mathrm{S}$ & $036^{\circ} 25^{\prime} 14.3^{\prime \prime} \mathrm{W}$ \\
\hline 6 & $07^{\circ} 48^{\prime} 48.3^{\prime \prime} \mathrm{S}$ & $034^{\circ} 57^{\prime} 16.0 ” \mathrm{~W}$ & $09^{\circ} 14^{\prime} 46.9^{\prime \prime} \mathrm{S}$ & $036^{\circ} 25^{\prime} 13.9^{\prime \prime} \mathrm{W}$ \\
\hline
\end{tabular}


previously sterilized glass jars, with some water from the sampling site, and transported to the laboratory. In the laboratory, the leaf litter was gently washed under tap running water and cut into fragments of approximately $1 \mathrm{~cm}^{2}$. The fragments were incubated in sterile Petri dishes, to which was added water from the sampling site and sterile distilled water (1:1, v/v), at room temperature (Silva et al., 2019). Every 2-3 days, the water from the plates was drained and substituted by fresh sterile distilled water. On the fifth day, observations of the leaf fragments, mounted between microscope slide and cover slip, were started under a phase-contrast light microscope. Four plates (submerged chambers) were prepared containing 10 leaf fragments each for each sampling point, totaling 40 fragments per point, 240 per area in each collection ( 480 per collection event) and 1920 fragments in the study (four collection events).

Part of the collected leaf litter was used for incubation in moist chambers, according to the method of Castañeda-Ruiz et al. (2016). Briefly, the leaves were gently washed for 30 minutes in a perforated plastic container, with no direct incidence of water on the leaves. Then, the leaves were quickly dried on paper, cut into fragments of approximately $7 \mathrm{~cm}^{2}$ to fit two fragments in each Petri dish lined with filter paper moistened with sterile distilled water (moist chamber). Two moist chambers for the first collection and four moist chambers for the remaining sampling events were set up for each sampling point, with 2 leaf fragments in each, resulting in 336 fragments evaluated in the study by this method. After 72 hours incubation, the observation of this material was initiated in a stereo microscope to locate the fungal structures, followed by mounting microscope slides with lactic acid for later observation under a light microscope. The observation period extended up to 60 days.

The fungi structures were compared with the species descriptions in the literature (e.g., Ellis, 1971, 1976; Ingold, 1975; Marvanová, 1997; Matsushima, 1985; Nilsson, 1964; Seifert et al., 2011) for specimen identification. For conservation of the identified specimens, slides with the specimen mounted in lactic acid and covered by a coverslip were sealed with colorless nail varnish.

\subsection{Analyses of the water abiotic variables}

At the sampling site, during the collection, the water temperature was measured with a digital thermometer. A water sample was collected, in a BOD-type bottle, for analysis of dissolved oxygen
(DO) using the Winkler method modified by Golterman (Jördening \& Winter, 2005). This water sample was fixed in the field by the addition of $2 \mathrm{ml}$ manganous sulfate solution and $2 \mathrm{ml}$ sodium azide solution (Macêdo, 2005).

Water samples from each location were also collected in $500 \mathrm{ml}$ plastic bottles, previously sanitized, for $\mathrm{pH}$ and electrical conductivity (EC) analysis. In the laboratory, a $50 \mathrm{ml}$ aliquot was removed for $\mathrm{pH}$ analysis, using a $\mathrm{pH}$ indicator strip (ForlabExpress, Brazil). Another aliquot of the same volume, from the same bottle, was used for measuring the $\mathrm{EC}$ in a bench conductivity meter (Simpla EC150, Brazil).

In addition to these variables, a few other variables were also included for determining the water quality index (WQI), which are: sulfate content, biochemical oxygen demand (BOD), chemical oxygen demand (COD), total and partial alkalinity, apparent and real color, quantitative acidity index, chlorides, and coliforms (using Chromagar medium), according to the APHA (1995). Nitrogen and phosphorus were determined by stoichiometric calculations, in the proportion of 2:3, from DO levels (Pohling, 2009). In addition to the water variables, the climatological data of the region, such as air temperature and rainfall, were obtained monthly from the website of the Agência Pernambucana de Águas e Clima (APAC).

\subsection{Calculation of the water quality index (WQI)}

The WQI of each study area was calculated using the product of abiotic variables raised to their respective weights (Table 2), using the Formula 1:

$$
W Q I=\prod_{i=1}^{n} q_{i}{ }^{w_{i}}
$$

in which WQI = Water Quality Index, represented by a number between 0 and 100; qi = quality of

Table 2. Parameters that compose the calculation of the WQI used to determine water quality and their respective weight.

\begin{tabular}{lc}
\hline \multicolumn{1}{c}{ Water quality parameter } & weight (w) \\
\hline Dissolved oxygen - DO & 0.17 \\
Thermotolerant coliforms & 0.15 \\
Hydrogenionic potential - pH & 0.12 \\
Biochemical oxygen demand - BOD $5,20^{\circ} \mathrm{C}$ & 0.10 \\
Water temperature & 0.10 \\
Total nitrogen & 0.10 \\
Total phosphorus total & 0.10 \\
Turbidity & 0.08 \\
Total residue & 0.08 \\
\hline
\end{tabular}

Source: ANA (2020). 
the $\mathrm{i}$-th parameter and $\mathrm{wi}=$ weight corresponding to the $\mathrm{i}$-th parameter (ANA, 2020). The qi value, which refers to the quality of parameter $i$, is a number between 0 and 100 obtained from the graph of each parameter depending on its concentration (Libânio, 2005). To calculate the WQI values for the water of CD Refuge and REBIO PT, the arithmetic averages of all values obtained for each variable involved in the calculation (all sampling points of all collections) were calculated.

The WQI value obtained for each area was compared with the intervals of the water quality standard, which are: $80<\mathrm{IQA} \leq 100$ (excellent), $52<\mathrm{IQA} \leq 79$ (good), $37<\mathrm{IQA} \leq 51$ (regular), 20 $<\mathrm{IQA} \leq 36$ (bad) and IQA $\leq 19$ (poor) (ANA, 2020).

\subsection{Statistical and ecological analyses}

Numerical data referring to the fungal community, as well as the abiotic variables for environmental characterization, were submitted to analysis of variance (ANOVA), with Tukey's test when appropriate, for comparison between the study areas, between sampling periods, and between sampling points of each area using Minitab 18 (Minitab LLC), according to Gotelli \& Ellison (2011). Cluster analysis (Dice similarity coefficient) and non-metric multidimensional scaling (NMDS, Jaccard coefficient) were used to investigate patterns in the fungi community structure and principal component analysis (PCA) was used to investigate whether these patterns were influenced by abiotic variables (Gotelli \& Ellison, 2011; Hair Junior et al., 2009) using Statistica 8.0 (Weiß, 2007). Correlation tests (Pearson) were used to indicate the relationship between water abiotic variables and the fungi community.

The richness, diversity, equitability and dominance of the hyphomycetes communities in each area were determined and the frequency of occurrence of species was calculated to classify species as dominant, most common, common and rare (Zhang et al., 2004).

\section{Results}

\subsection{Occurrence, richness and diversity of aquatic hyphomycetes}

In this work, 53 taxa of hyphomycetes were recorded with 1926 occurrences in 2592 fragments of decomposing leaves, 32 taxa and 1023 occurrences in 1296 fragments originating from the REBIO PT and 44 taxa and 903 occurrences in 1296 fragments of the CD Refuge (Table 3). Of the 53 taxa recorded, 11 are ingoldian fungi, 28 are lignicolous hyphomycetes (or facultative-aquatic) and 14 could not be identified due to the absence of diagnostic characteristics necessary for specimen confirmation, being designated as sp.

Xylomyces acerosisporus was detected in large quantities in all sampling points of the two collection areas, being considered typically tropical in the Atlantic Forest. In general, CD Refuge (44 taxa) showed greater richness than REBIO PT (32 taxa). The dominant taxa in the study were $X$. acerosisporus (361 records), Triscelophorus monosporus (242), Flagellospora sp. (232), X. giganteus (231), Blodgettia aquatica (160), F. penicillioides (157) and B. indica (135).

The least representative taxon in the REBIO PT, which occurred only once, was Speiropsis scopiformis. As for the CD Refuge, the species with only one occurrence (rare) were: Acumispora verruculosa, Circinotrichum olivaceum, Dinemasporium lanatum, Endophragmiella curvata, Linodochium sideroxyli, Lunulospora curvula, Phaeoisaria infrafertilis, Phaeoisaria sp., Variocladium sp., Vermiculariopsiella cubensis and Wiesneriomyces laurinus (Table 3).

Some species had their occurrence detected in both the moist and the submerged chamber: F. penicillioides, Flagellospora sp., T. monosporus, W. laurinus, $X$. acerosisporus, $X$. aquaticus, $X$. chlamydosporus and $X$. giganteus.

Of the detected taxa, 15 were registered exclusively in CD Refuge, 36 were common between the two areas and none was exclusive of the REBIO PT. The similarity of the hyphomycetes communities between the two areas $(-50 \%)$ is shown in Figure 1. The sampling points in each area formed two large groups with greater similarity between sampling points in the area (group) than with points in the other area, except for $\mathrm{CD} 3$, which was grouped with the PT community.

Species richness, which ranged from 44 in CD Refuge to 32 in REBIO PT, and evenness, with variation from 0.951 in CD Refuge to 0.992 in REBIO PT, were the two ecological indices that differed significantly between the study areas (Table 4). Diversity and dominance did not differ significantly (Table 4) and dominance was low.

The structure of the hyphomycetes community, according to the sampling points of each area is represented in Figure 2. The distance between the markings in the graph indicates dissimilarity between the hyphomycetes communities; therefore, 


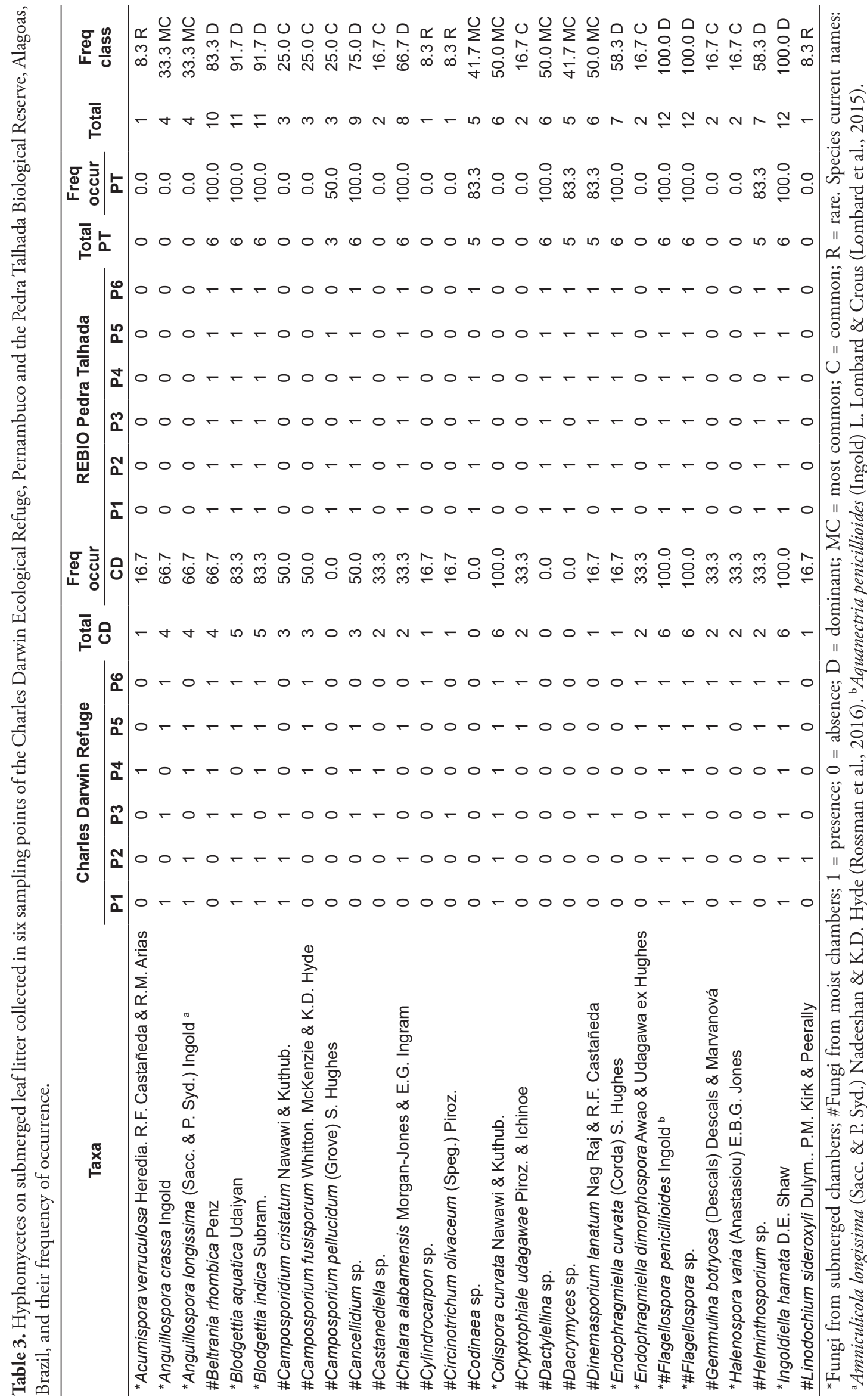




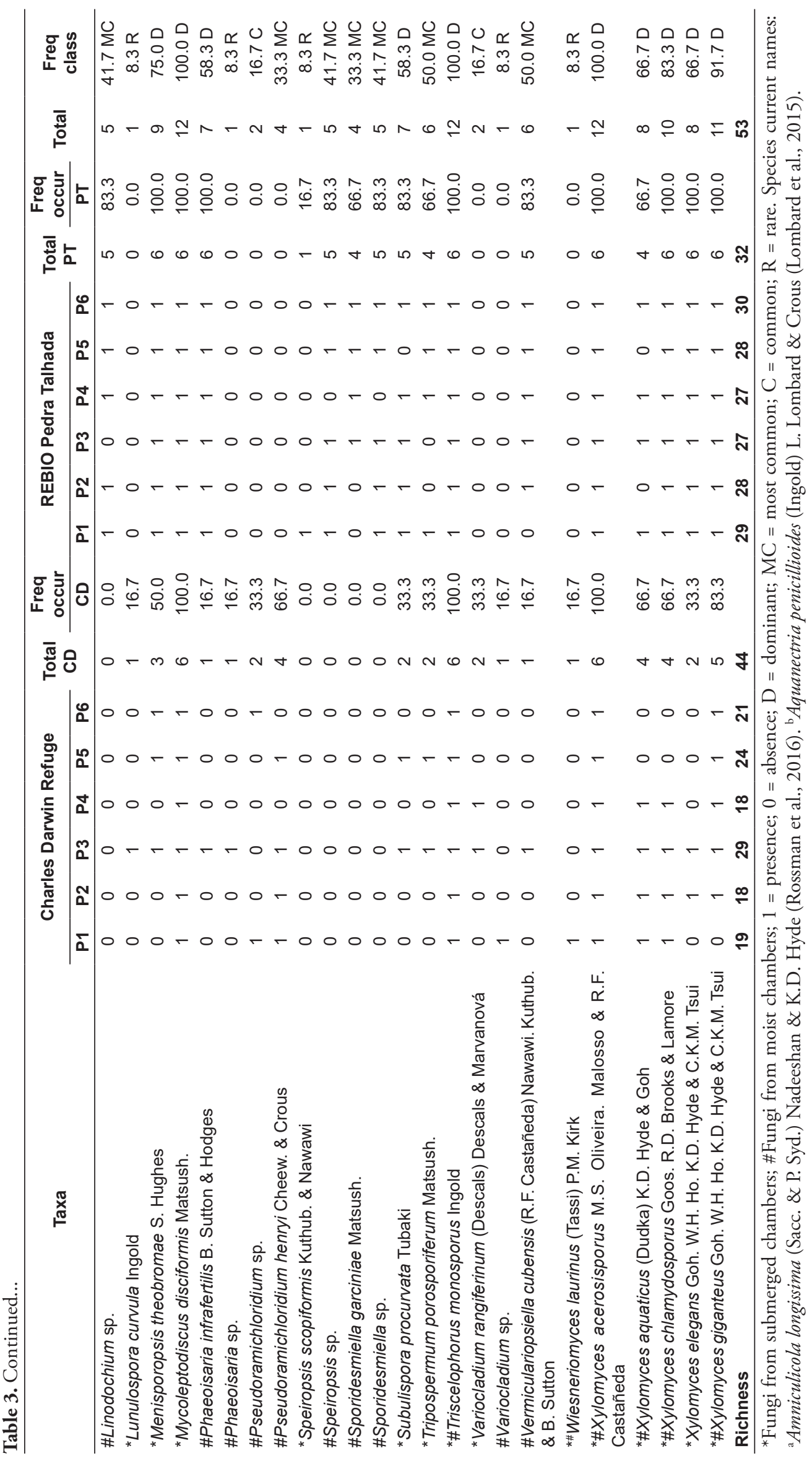


it is observed that the hyphomycetes community in CD Refuge is much more heterogeneous along the stream than that in the REBIO PT.

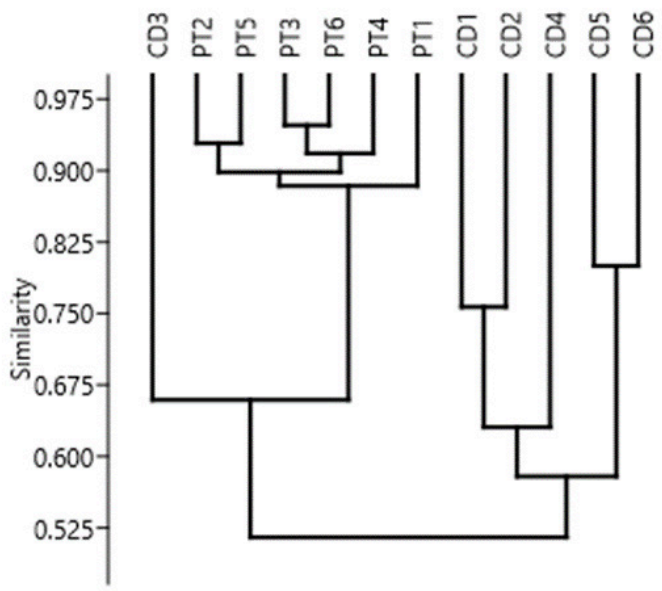

Figure 1. Similarity between the communities of hyphomycetes on submerged leaf litter from Pedra Talhada Biological Reserve (PT) and Charles Darwin Ecological Refuge (CD), according to Dice coefficient.

\subsection{Physical-chemical characterization of the water}

The averages of sampling point values of water physical and chemical variables in each collection expedition to CD Refuge and REBIO PT are shown in Table 5. All measured variables presented some significant difference between sampling periods.

Acidity and alkalinity are reported as concentration $\left(\mathrm{mg} . \mathrm{L}^{-1}\right)$ of $\mathrm{CaCO}_{3}$ in the water sample, but their values are obtained from titration with a strong alkali or strong acid, respectively, indicating the neutralizing capacity of the water sample up to a specific pH (Sekerka \& Lechner, 1984). Both variables showed significant difference between 2018 and 2019 for both study areas. Higher concentration for acidity was in the rainy season of 2018 in CD Refuge and dry season for REBIO PT (Table 5). Alkalinity was higher in the dry season 2019 for CD Refuge and rainy season 2018 for REBIO PT (Table 5). Alkalinity was also significantly higher in CD Refuge when the two areas were compared. The water $\mathrm{pH}$ ranged from slightly acidic to slightly neutral in CD Refuge

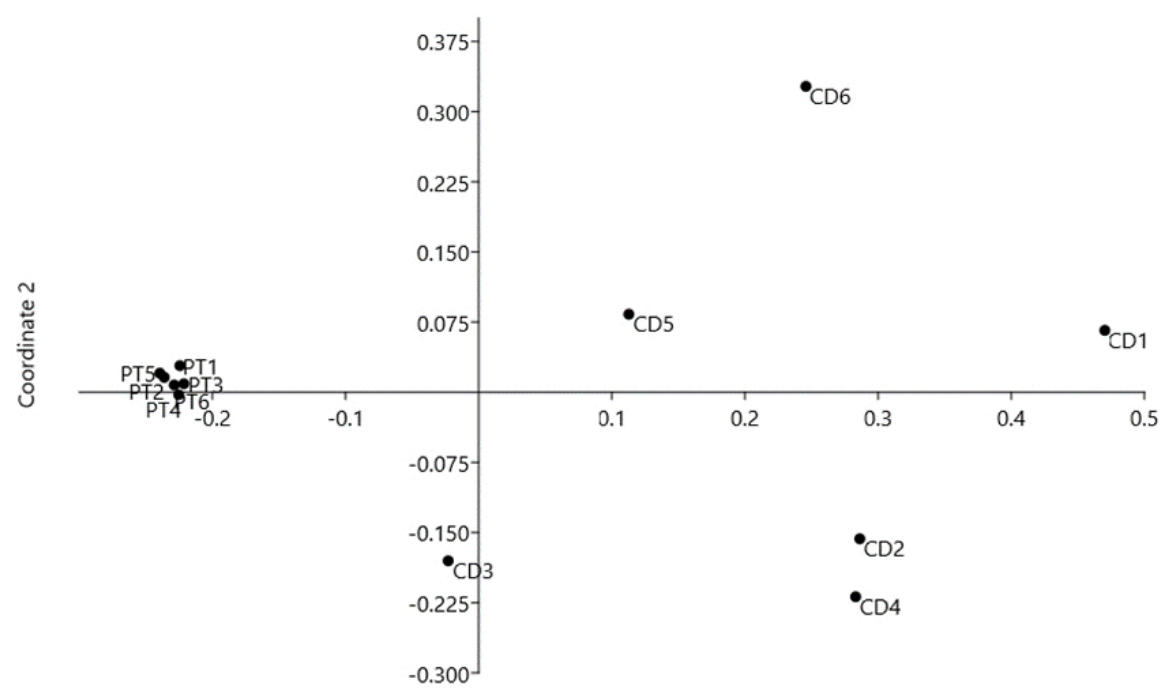

Coordinate 1

Figure 2. Non-metric multidimensional scaling analysis of the hyphomycetes communities on submerged leaf litter from Pedra Talhada Biological Reserve (PT) and Charles Darwin Ecological Refuge (CD), according to Jaccard coefficient (stress $=0.08243$ ).

Table 4. Species richness, Shannon-Wiener's diversity (H'), Pielou's equitability (J') and Berger-Parker's dominance (d) of hyphomycetes on leaf litter submerged in streams of the Charles Darwin Ecological Refuge (CD) and Pedra Talhada Biological Reserve (PT).

\begin{tabular}{cccc}
\hline Indices & CD & PT & Perm p(eq) $^{*}$ \\
\hline Richness & 44 & 32 & 0.0066 \\
Shannon_H & 3.6 & 3,438 & 0.0851 \\
Equitability_J & 0.951 & 0.992 & 0.0002 \\
Berger-Parker & 0.046 & 0.035 & 0.24 \\
\hline
\end{tabular}

"Perm $\mathrm{p}(\mathrm{eq})$ : probability of having equal diversities. If $\mathrm{p}(\mathrm{eq})>0.05=$ non-significant. 


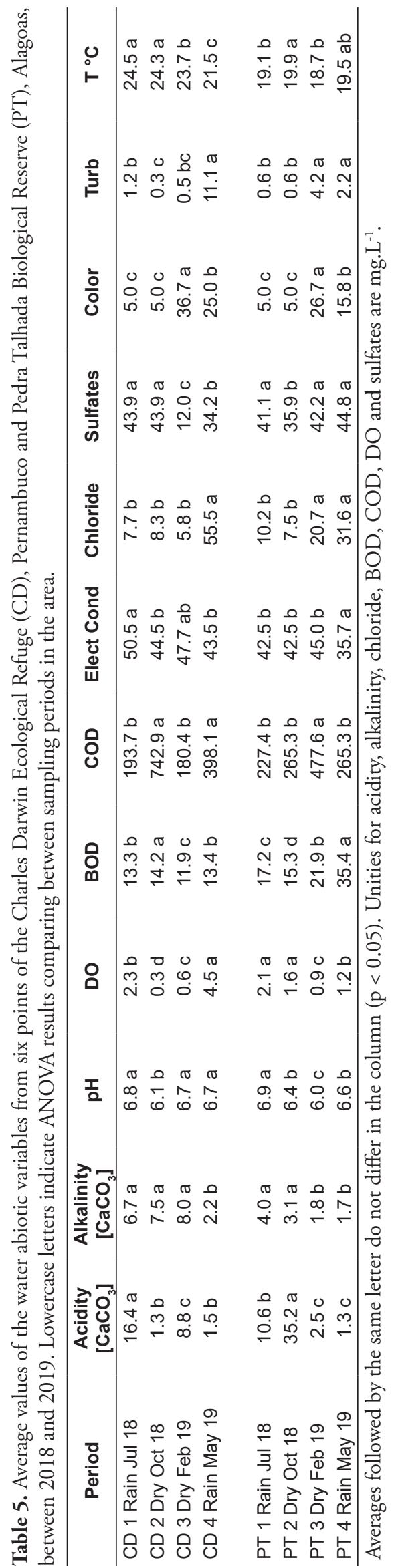


(6.1 to 6.7) and in REBIO PT (6.0 to 6.9), and there was no significant difference between study areas.

The levels of dissolved oxygen (DO) in the water of CD Refuge varied from 0.27 to $5.9 \mathrm{mg}$. $\mathrm{L}^{-1} \mathrm{O}_{2}$ with significant difference in the averages between sampling periods. In the REBIO PT, DO variation was from 0.7 to $2.35 \mathrm{mg}$. $\mathrm{L}^{-1} \mathrm{O}_{2}$ which was also significantly different between sampling periods. The areas did not differ significantly in relation to DO. The same difference between rainy and dry season was detected for BOD in both areas, however, COD differences did not seem to be related to the climatic seasons.

Electrical conductivity in the water of CD Refuge was significantly higher in the rainy period of 2018 while in REBIO PT this variable was significantly lower in the rainy period of 2019. Chloride content in the water was significantly higher in the rainy season of 2019 in both areas. The concentration of sulfates in CD Refuge varied from 12 to $43.9 \mathrm{mg} . \mathrm{L}^{-1}$, representing a percentage increase of $73 \%$ between the rainy and dry seasons while, in REBIO PT, this increase was approximately $14.7 \%$ between the first and last sampling events. The color of the water in the two study areas was significantly darker in 2019 and did not vary according to the seasons. Turbidity increased from 0.33 to $1.11 \mathrm{NTU}$ at the CD Refuge between the rainy and dry seasons, corresponding to an increase of $97 \%$. For REBIO PT, turbidity varied from 0.5 to 4.2 NTU between the seasons, corresponding to an increase of $76 \%$.

Water temperature was significantly lower in REBIO PT with lowest record in the dry season of
2019. In CD Refuge, water temperature differed between 2018 and 2019 and did not follow season variation.

The analysis of abiotic variables (standardized by the $\log \mathrm{X}+1$ transformation) using the principal component analysis method (Figure 3 ) showed that there was no separation of the areas evidenced by these variables, however, there was a better structured grouping according to the collection periods for the CD Refuge. The two extracted components explained $55.63 \%$ of data variation.

The variables used for the analysis of the WQI are shown in Table 6 . The calculation resulted in a WQI of 40.46 for CD Refuge and 39.77 for REBIO PT.

According to the ANA classification, the water in the two study areas was classified as regular, even though they have been sampled in areas of environmental protection.

\section{Discussion}

\subsection{Hyphomycetes community}

Richness and occurrence of hyphomycetes in submerged leaf litter of CD Refuge and REBIO PT were studied by methods of analyses that favor the development of ingoldian fungi, but does not prevent the development of other hyphomycetes. This allows a better diagnostic of the diversity.

The number of fungal species, registered from submerged substrates in studies in Brazil, indicates that richness of aquatic fungi is high in the CD Refuge and REBIO PT. Some studies carried out in the country showed fewer species, for example,
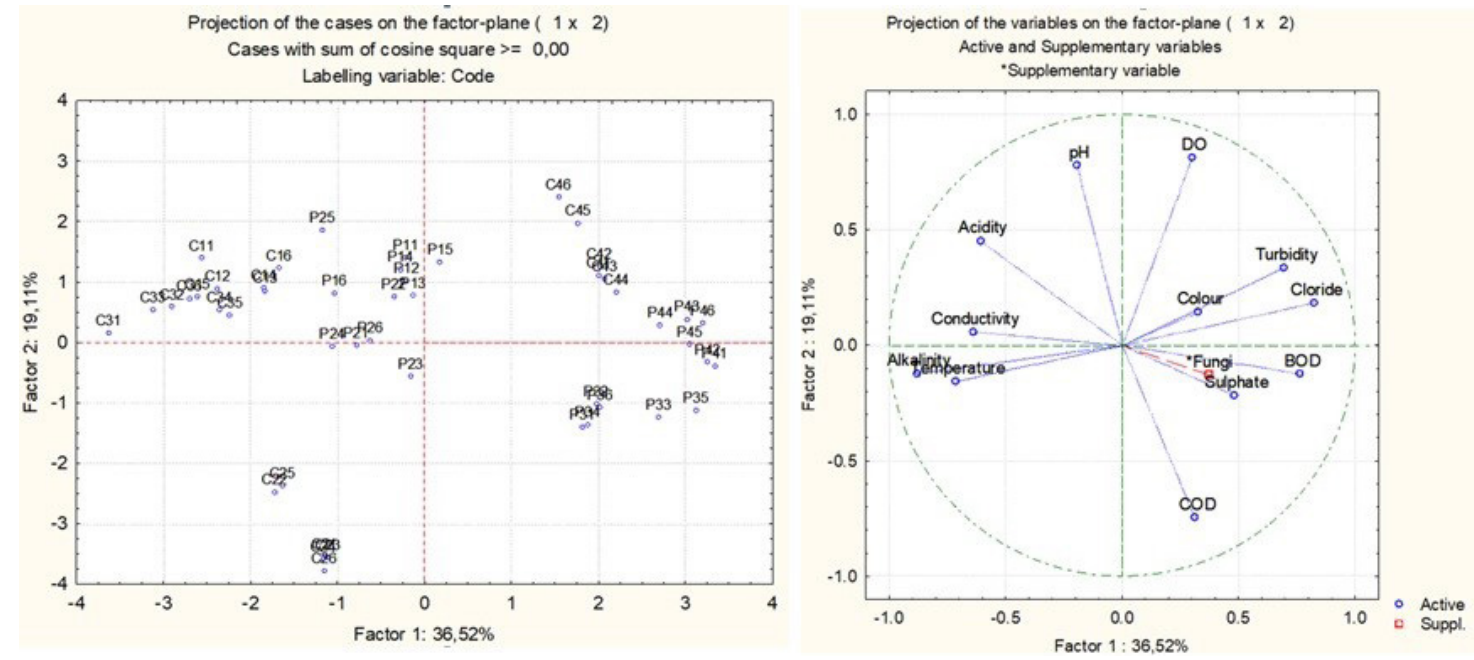

Figure 3. Principal component analysis of the abiotic variables measured in the water collected from Charles Darwin Ecological Refuge (C) and Pedra Talhada Biological Reserve (P) along four sampling periods, plus the number of fungal species detected as supplementary variable. 
Table 6. Parameters included in the calculation of the WQI for Charles Darwin Refuge (CD) and REBIO Pedra Talhada (PT) and their respective weight.

\begin{tabular}{|c|c|c|c|c|c|c|}
\hline \multirow{2}{*}{ Parameter name } & \multirow{2}{*}{ Unity } & \multicolumn{2}{|c|}{ Result of the sample } & \multicolumn{2}{|c|}{ Qi } & \multirow{2}{*}{ w(weight) } \\
\hline & & CD & PT & CD & PT & \\
\hline Thermotolerant coliforms (q1) & $\mathrm{NMP} / 100 \mathrm{ml}$ & $10^{-5}$ & $10^{-5}$ & 9.0 & 9.0 & 0.15 \\
\hline $\mathrm{pH}(\mathrm{q} 2)$ & & 6.46 & 6.67 & 80 & 80 & 0.12 \\
\hline BOD (q3) & $\mathrm{mg} / \mathrm{L}$ & 1.33 & 0.55 & 95 & 92 & 0.10 \\
\hline Total nitrogen (q4) & $\mathrm{mg} / \mathrm{L}$ & 1.06 & 0.46 & 92 & 90 & 0.10 \\
\hline Total phosphorus total (q5) & $\mathrm{mg} / \mathrm{L}$ & 2.15 & 2.89 & 28 & 26 & 0.10 \\
\hline Temperature (q6) & ${ }^{\circ} \mathrm{C}$ & 24.5 & 19.5 & 9.0 & 9.0 & 0.10 \\
\hline Turbidity (q7) & NTU & 0.29 & 0.35 & 100 & 100 & 0.08 \\
\hline Total residue (q8) & $\mathrm{mg} / \mathrm{L}$ & 0.13 & 1.78 & 80 & 80 & 0.08 \\
\hline $\mathrm{DO}(\mathrm{q} 9)$ & $\mathrm{mg} / \mathrm{L}$ & 155.5 & 175.9 & 47 & 47 & 0.17 \\
\hline
\end{tabular}

Moreira (2011) found 33 taxa and SchoenleinCrusius et al. (2014) detected 27 taxa in São Paulo, and Silva et al. (2019) found 23 taxa in Pernambuco. However, in streams of Paraná, Scoarize (2018) accounted to 56 identified species, that is a slightly larger number of species than the reported in this study. Studies carried out in several countries have reported smaller numbers of species than the present study e.g., Bärlocher \& Rosset (1981): 42 species in Germany, Gulis \& Suberkropp (2003): 33 species in the USA, Baudoin et al. (2008): 37 species in France, Bärlocher et al. (2010): 33 species in Panama, but also, in addition to this list, some studies reported larger numbers than ours such as Chauvet (1991): 54 species in other locality of France, Bärlocher (2000): 77 species in Canada, Rajashekhar \& Kaveriappa (2003): 66 species in India, Czeczuga et al. (2005): 65 species in Poland. This variation strongly indicates that specific local conditions are more important than geographic position to determine species richness (Duarte et al., 2016).

The contribution of Brazilian studies to the knowledge of aquatic fungi in South America has been quite expressive (Schoenlein-Crusius \& Grandi, 2003; Fiuza et al., 2017). The studies of aquatic hyphomycetes in Brazil started in São Paulo (Schoenlein-Crusius \& Milanez, 1989), in the Atlantic Forest biome, and were later carried on to different regions and biomes like the Amazon (Monteiro \& Gusmão, 2013; Fiuza et al., 2015; Krause et al., 2020), Caatinga (Almeida et al., 2011; 2012; Barbosa \& Gusmão, 2011; Fiuza \& Gusmão, 2013) and Cerrado (Malosso, 1999; SchoenleinCrusius, 2002). In the Atlantic Forest of the Northeast, Cavalcanti \& Milanez (2007), Oliveira (2016) and Silva et al. (2019) added contributions to the knowledge. From a quantitative point of view, 59 species of aquatic hyphomycetes were known in Brazil until 2003 (Schoenlein-Crusius \& Grandi, 2003). Fiuza et al. (2017) registered in their checklist the new taxa that had been described after 2003 and increased the number of known species in Brazil to 85, with 53 species known from the Atlantic Forest. In this study, 11 species of aquatic hyphomycetes (ingoldian fungi) were detected, which represents $-13 \%$ of the known diversity for the country and $-21 \%$ for the biome.

There was a larger number of fungal species identified in the CD Refuge material when compared to the material from the REBIO PT. It was observed that Blodgettia aquatica, B. indica and Xylomyces acerosisporus were present in the CD Refuge in greater density of conidia or chlamydospores, arising from profusely branched mycelia. In the REBIO PT, they occurred as individual scattered conidia or chlamydospores on the leaf and/or petiole. In this work, this pattern of occurrence may be due to three factors: the botanical family of the collected leaves (Chauvet et al., 2016; Fiuza et al., 2019), the quantity of nutrients dissolved in the water (Danger et al., 2016) and the period of leaf collection (Sridhar et al., 2011). All taxonomic structures of Blodgettia aquatica and $B$. indica were detected in angiosperm leaves (pinned venation). Xylomyces species were detected in heterogeneous litter, with a higher occurrence in angiosperms. Mycoleptodiscus disciformis was also easily detected in heterogeneous litter, although its occurrence has been detected specifically in the leaf blade. Ingoldiella hamata had its occurrence verified in the leaf petiole, usually of gymnosperms. Similar observations have not been found yet in the literature.

The incubation methods used for fungi development in the laboratory is crucial for detecting greater richness and diversity in a given group of hyphomycetes (lignicolous or facultative 
aquatic, aero-aquatic and ingoldian). In this study, two methods were used: incubation in submerged chamber, to facilitate the detection of aquatic hyphomycetes and incubation in moist chamber, which is used to observe the structures of aeroaquatic hyphomycetes. Although each method favors a specific group of fungi, in this study it was found that typical aquatic hyphomycetes can eventually be observed in moist chamber, like the ingoldian Triscelophorus monosporus, Flagellospora penicillioides and Flagellospora sp., as well as terrestrial hyphomycetes can also be detected in submerged chamber, for example, Wiesneriomyces laurinus. Although each technique is important for determining the occurrence of species in each group of hyphomycetes, none was completely restrictive to the detection of species of the other group, which agrees with the conclusions of Fiuza et al. (2019).

Most species had their occurrence reported in the two study areas. However, emphasis should be given to the species of Xylomyces, which was detected at all sampling points of all sampling periods in both study areas, and also to species of Triscelophorus (Sridhar et al., 2011; Schoenlein-Crusius et al., 2014) and Flagellospora (Fiuza et al., 2019), which had high numbers of occurrence, mainly in the CD Refuge. An interesting observation is that Xylomyces spp. were detected more frequently at the edges of the leaf structure, showing abundant catenate chlamydospores. It is not yet clear whether this occurrence was fortuitous or if it really is a feature of this genus. The species of Flagellospora, in contrast, occurred similarly on the leaves parts and their conidiophores were detected frequently in the leaf litter found near foams produced by the natural movement of the water in the stream. Most aquatic fungi, especially hyphomycetes, are cosmopolitan (Wood-Eggenschwiler \& Bärlocher, 1985; Wong et al., 1998), and many can survive adverse conditions, which increases the similarity of the communities in different environmental conditions (Gulis \& Suberkropp, 2003).

The collections were carried out over a period of one year, varying between rainy and dry seasons. In the rainy season, the number of species observed is greater than in the dry season. It is known that in the rainy season the quantity of nutrients increases, especially nitrogen and phosphorus components, making the water darker with increasing decomposition and BOD (Suberkropp \& Chauvet, 1995; Sridhar \& Bärlocher, 2000; Grattan II \& Suberkropp, 2001; Rosemond et al., 2002). Eutrophication caused by anthropic activities, as observed in one of CD Refuge's sampling points, also affects water quality due to the increase in nutrient content and consequent reduction of DO. In the dry season, the water in the sampling sites was clearer and with less natural foam.

Microorganisms associated with submerged leaf litter, such as hyphomycetes, can capture nitrogen (Sridhar \& Bärlocher, 2000) and phosphorus (Mulholland et al., 1984) for their biological development directly from the water column, when these nutrients are abundant. This could cause, for example, a delay in the decomposition of leaf litter since it will be less colonized because more energy is needed to obtain from the litter the same compounds that are free in water (Gonçalves Junior et al., 2007; Sales et al., 2015). A delay in colonization was observed in the leaf litter of both CD Refuge and REBIO PT in the rainy periods, when the water was darker and full of debris. In the dry period, submerged leaf litter showed a higher degree of decomposition with more associated hyphomycetes. Graça et al. (2015) also reported that for tropical streams, in drier periods, the rate of leaf decomposition can be higher than in rainy periods, when the nutrients' supply is higher.

The studied areas also showed differences in community composition, richness, and diversity of hyphomycetes, especially ingoldians. In the REBIO PT (688-699 m.a.s.l.), the number of typical aquatic hyphomycetes (ingoldians) was smaller than in the CD Refuge (36-44 m.a.s.l). Abiotic factors such as temperature (correlation -0.13), oxygen saturation (correlation +0.39) and altitude (Chauvet, 1991; Rajashekhar \& Kaveriappa, 2003) can influence these numbers.

Altitude has not been specifically evaluated in this study, since the analyses of the areas imply the difference. Regarding the effect of elevation, Rajashekhar \& Kaveriappa (2003) concluded that altitude did not have a direct effect on the occurrence of fungi. It had indirect effects such as variation in temperature, vegetation, and rainfall that may be responsible for the differences in species richness in their study. For the REBIO PT, when the temperature increased, a larger number of fungi was detected while in the CD Refuge, Pearson's correlation coefficient for temperature and the number of fungi in general was negative $(-0.66)$. This means that when temperature increases, a smaller number of hyphomycetes was detected in this site. Regarding the DO content, according to the correlation test $(+0.69)$, the higher DO concentration the larger the number of fungi 
detected, reinforcing the idea that this variable is important for occurrence of (typically aerobic) hyphomycetes in the water (Medeiros et al., 2009).

\subsection{Water quality in the sampling sites and its relationship with the hyphomycetes}

The range of variation of abiotic variables detected in this work fell within the ranges of studies in tropical streams (Bärlocher et al., 2010; Fernández et al., 2017; Fiuza et al., 2019; Moro \& Schoenlein-Crusius, 2020). Four water variables are commonly discussed in studies of aquatic hyphomycetes (DO, EC, $\mathrm{pH}$ and temperature). $\mathrm{DO}$ is the main variable as it presents significant differences throughout the year in the CD Refuge and a positive correlation (0.69) with the occurrence of hyphomycetes. Ingoldian hyphomycetes are often found in well-aerated water, notably Flagellospora spp. and Triscelophorus monosporus (Bärlocher et al., 2010; Schoenlein-Crusius et al., 2015; Moro \& Schoenlein-Crusius, 2020). The DO is important for the occurrence of other organisms in the water; therefore, CONAMA Resolution 357/2005 establishes that, in any sample, the concentrations of DO should not be lower than $6 \mathrm{mg} \cdot \mathrm{L}^{-1} \mathrm{O}_{2}$ (Brasil, 2005). The fact that the detected DO is lower than the CONAMA recommendation in the studied areas can be understood when one confront these data with the values of COD, since high COD decreases DO. Medeiros et al. (2009) discussed that the low levels of DO directly affect leaf decomposition due to the decrease in the occurrence of fungi while Scoarize (2018) reported that when the DO is low, the organisms adapt to the scarcity of the element by producing more chlamydospores. Oliveira (2016) and Rasvailer et al. (2020) were able to detect aquatic hyphomycetes at low concentrations of DO. However, it was at higher concentrations, although below the values determined by Ordinance No 2914/2011 (Brasil, 2011), that Moro \& Schoenlein-Crusius (2020) were able to identify 39 species of hyphomycetes.

The electrical conductivity showed a correlation of -0.47 at CD Refuge with the occurrence of detected fungi, and of -0.37 at REBIO PT, confirming that the increase in EC (sometimes indicating pollution) reduces fungal occurrence. Bärlocher et al. (2010) reported that the number of fungal species was high in pristine streams (low EC) and declined in rural and urban streams (high EC). However, they did not consider any of the fungi species encountered as consistent indicators of pristine or stressed streams.
The temperature was significantly different between the two study areas and between the sampling events, and showed a strong correlation with the fungal community at the CD Refuge (-0.75). At the REBIO PT, however, the correlation between temperature and fungal community was weak and non-significant $(-0.01)$.

In the present study, it was observed that specimens of Triscelophorus monosporus were not detected at temperatures above $24{ }^{\circ} \mathrm{C}$ and Xylomyces acerosisporus was detected at temperatures ranging from $19{ }^{\circ} \mathrm{C}$ to $24.5^{\circ} \mathrm{C}$. Flagellospora sp. was mainly detected at sampling points where temperature was $19.5^{\circ} \mathrm{C}$. At the REBIO PT, the altitude contributes to lower water temperature, compared to the CD Refuge, however, fungal occurrence did not differ significantly. In the dry season, the water temperature at the REBIO PT varied between $19{ }^{\circ} \mathrm{C}$ and $21.5^{\circ} \mathrm{C}$, when a larger number of facultative hyphomycetes was recorded. Several studies have related temperature to the occurrence of hyphomycetes: Chauvet $\&$ Suberkropp (1998) discussed that temperature may be a factor that selects certain species of hyphomycetes while Fernandes et al. (2009) found that changes in temperature altered the composition of fungal species and led to changes in leaf litter decomposition. Moro \& Schoenlein-Crusius (2020) reported that temperature influenced the amount of hyphomycetes identified on an island in southeastern Brazil, and found more frequently Triscelophorus monosporus, Lunulospora curvula, and Tripospermum camelopardus in a temperature range between $18{ }^{\circ} \mathrm{C}$ and $24^{\circ} \mathrm{C}$.

Turbidity is not commonly assessed in aquatic hyphomycetes studies; however, it was one of the variables that correlated significantly with the occurrence of aquatic or facultative hyphomycetes in this work (correlation 0.47 for CD Refuge and 0.63 for REBIO PT). At the CD Refuge, there was an increase in turbidity in $\mathrm{C} 4$, when a higher number of aquatic hyphomycetes was recorded. Xylomyces giganteus, X. aquaticus, Blodgettia indica, B. aquatica, Flagellospora sp., F. penicillioides, Triscelophorus monosporus, and Mycoleptodiscus disciformis were largely recorded in this period. This can be explained by the increase in the content of organic particulate matter in the water available for decomposition and, consequently, an increase in the occurrence of fungi. Contrarily, at the REBIO PT, during C4, turbidity decreased probably due to dilution caused by the rainfall, and the number of hyphomycetes detected nearly doubled, compared 
to the previous sampling. The lack of consistency between the two areas could be discussed according to Bärlocher et al. (2010) that affirmed that total suspended solids and turbidity are potential indicators of more intensive land use resulting in increased runoff and erosion. This leads to oxygen limitation, which can interfere with the occurrence of microorganisms in the aquatic environment and reduce the efficiency of decomposition. However, it does not explain higher sporulation.

No significant $\mathrm{pH}$ variation was observed between the studied areas or between sampling points. The first studies of aquatic hyphomycetes reporting on the influence of $\mathrm{pH}$ date back to the 1960s (Suzuki \& Nimura, 1960; 1961). They found more fungal species at what they considered to be harmonic $\mathrm{pH}(6.2-6.5)$ than in acidic waters ( $\mathrm{pH}$ 3.8-5.8). Chamier (1992) compiled research findings from temperate regions and suggested that diversity is greater in circumneutral rivers and reduced in alkaline or acidic rivers. Since then, basically all studies with an ecological bias (Bärlocher et al., 2010; Schoenlein-Crusius et al., 2015; Fernández et al., 2017; Fiuza et al., 2019) have measured $\mathrm{pH}$ and found very similar results, confirming Chamier's suggestion.

BOD differed between sampling periods in both areas, being significantly higher in the REBIO PT, where it also presented a strong correlation with the fungal community $(+0.71)$. Although the organic matter can be one source of nutrition to aquatic hyphomycetes, Sridhar \& Raviraja (2001) discussed that increased BOD could be detrimental to the abundance and activity of aquatic hyphomycetes. Ortiz-Vera et al. (2018) conducted a study along the Tietê River, in São Paulo, and found that the physicochemical factors best explaining fungal diversity patterns were $\mathrm{pH}$ and dissolved iron, while community composition was mostly influenced by BOD, pH, DO, and seasonality. In their study based exclusively on molecular data, sites that presented higher $\mathrm{pH}$ and higher BOD showed enrichment of some specific OTUs (Ortiz-Vera et al., 2018).

COD did not vary significantly in the REBIO PT, except in the 2019 dry season, when the average value was almost twice the values previously observed. At the CD Refuge, there were clearly two levels of COD that did not follow the wet and dry seasons. No direct relationship was detected between COD and the occurrence of hyphomycetes (correlation 0.02), which represents, for this study, that COD does not interfere in the detection of aquatic hyphomycetes. However, Pascoal et al.
(2005) and Czeczuga et al. (2005) measured COD in water bodies in Portugal and Poland and found that the COD influence the occurrence of various fungal species in the aquatic environment.

Acidity and alkalinity are rarely used as parameters in studies of aquatic hyphomycetes, although they are known to interfere in the occurrence of aquatic organisms (Libânio, 2005). In this study, when acidity in the water decreased, higher occurrence of hyphomycetes was detected (correlation -0.52 for CD Refuge and -0.6 for REBIO PT). Acidity and alkalinity levels may interfere with $\mathrm{pH}$, although the variation observed in this study for the former variables was not mirrored in the $\mathrm{pH}$ that remained reasonably stable throughout the year. It is yet to be proved whether the decrease in alkalinity in the third and fourth samplings in REBIO PT, coinciding with the maximum number of conidia, or other taxonomic structures of aquatic hyphomycetes detected, was random. Decrease in alkalinity was generally accompanied by an increase in the detection of facultative hyphomycetes of the genus Xylomyces.

Variables such as chloride, sulfates, and color were registered in some studies (Graça, 1994; Czeczuga et al., 2005; Bärlocher et al., 2010) for water characterization but have not been discussed relating to the fungal community. In this work, we noted that at the CD Refuge, higher chloride concentration coincides with a high occurrence of aquatic hyphomycetes and sulfates, commonly associated with pollution (Krauss et al., 2003), showed a moderate negative correlation $(-0.52)$ with the fungal community.

\subsection{Water quality index (WQI)}

The CD Refuge and the REBIO PT had regular WQI (above 36 and less than or equal to 51), according to the ANA (2020) classification. The interpretation of the results of WQI evaluation must consider the intended use of water. For example, a low WQI value indicates the poor quality of water for human supply, but this water can be used in less demanding processes, such as navigation or power generation (Libânio, 2005). Both the CD Refuge and the REBIO PT showed values much lower than 79 , indicating that physical and chemical treatment of the water are necessary before distribution to the population.

The preference for cleaner and clearer waters was an important factor to justify the occurrence of hyphomycetes in the studied areas that are protected by conservation laws. Although one sampling point 
(point 6) at the CD Refuge presents strong human influence, it was the last sampled point downriver, and it has not contributed to a negative assessment of the water within the reserve. In REBIO PT, all sampling points are natural, with no anthropic influence, and the WQI showed no significant difference relating to $\mathrm{CD}$ Refuge despite one impacted sampling point.

Ingoldian hyphomycetes had their occurrence verified more frequently in CD Refuge, mainly in the more anthropized sampling point. When the two areas are compared in terms of ingoldian hyphomycetes, the highest occurrence in REBIO PT was at point 1 , a pristine region with accumulated dead organic matter. The only study that mentions specifically WQI and aquatic hyphomycetes is that of Ortiz-Vera et al. (2018). They used Terminal Restriction Fragment Length Polymorphisms (TRFLP) to evaluate broad diversity patterns, and ITS DNA sequencing from seven locations, representing a gradient of water quality, to determine taxonomic identity and composition patterns. They recorded that the aquatic communities of hyphomycetes showed decreasing similarity with increasing geographic distance. However, based on the River Continuum Concept, they argued that this pattern could reflect an interaction of, for example, hydrological conditions, riparian vegetation, substrate, and dispersal factors. Either way, the WQI was considered a useful parameter to compare the number of microorganisms present in the water.

\section{Conclusions}

Preserving natural areas of the Atlantic Forest is essential for the conservation of aquatic communities and diversity of hyphomycetes that decompose submerged leaf litter. Conservation Units are important for keeping riparian forests preserved and the good water quality, therefore assuring the reproductive success of aquatic fungi in these environments. In addition, the structure of the aquatic hyphomycetes community is also influenced by water quality, with a higher amount of hyphomycetes being found in cleaner waters.

Geographical factors such as altitude, temperature, and rainfall influence oxygen saturation in the water and oxygen has a direct correlation with the fungal community.

The variables determined in this work, and which are related to water quality standards, present values within the expected range for sites under environmental protection. The calculation of the
WQI is important for the determination of water quality and represents a useful ecological tool for detecting water pollution in natural reserves.

\section{Acknowledgements}

This research was supported by funds from CNPq/ICMBio (421241/2017-9) and CAPES (88881.062172/2014-01). The authors are also thankful to the Bioprocess and Industrial Processes Laboratory of the Chemistry Department of the Instituto Federal de Pernambuco for the facilities needed to evaluate WQI variables, to the Post-Graduation Program in Biology of Fungi (PPGBF) and the Department of Mycology of the Universidade Federal de Pernambuco for the facilities.

\section{References}

AGÊNCIA NACIONAL DE ÁGUAS - ANA. Portal da qualidade das águas: indicadores de qualidade da água: Indice de Qualidade das Águas (IQA) [online]. 2020 [viewed 24 Mar. 2020]. Available from: http:// portalpnqa.ana.gov.br/indicadores-indice-aguas.aspx

ALMEIDA, D.A.C., BARBOSA, F.R. and GUSMÃO, L.F.P. Alguns fungos conidiais aquáticos-facultativos do bioma Caatinga. Acta Botanica Brasílica, 2012, 26(4), 924-932. http://dx.doi.org/10.1590/S010233062012000400021.

ALMEIDA, D.A.C., IZABEL, T.S.S. and GUSMÃO, L.F.P. Fungos conidiais do bioma Caatinga I. Novos registros para o continente americano, Neotrópico, América do Sul e Brasil. Rodriguésia, 2011, 62(1), 43-53. http://dx.doi.org/10.1590/21757860201162104

AMERICAN PUBLIC HEALTH ASSOCIATION - APHA. American Water Works Association AWWA. Water Environment Federation - WEF. Standard methods for the examination of water and wastewater. 19th ed. Washington: APHA/AWWA/ WEF, 1995.

BARBOSA, F.R. and GUSMÃO, L.F.P. Conidial fungi from semi-arid Caatinga Biome of Brazil. Rare freshwater hyphomycetes and other new records. Mycosphere, 2011, 2(4), 475-485.

BARBOSA, F.R., GUSMÃO, L.F.P. and BARBOSA, F. Fungos anamórficos (Hyphomycetes) no semi-árido do Estado da Bahia, Brasil. Acta Botanica Brasílica, 2008, 22(1), 29-36. http://dx.doi.org/10.1590/ S0102-33062008000100004.

BÄRLOCHER, F. and ROSSET, J. Aquatic hyphomycete spora of two Black Forest and two Swiss Jura streams. Transactions of the British Mycological Society, 1981, 76(3), 479-483. http://dx.doi.org/10.1016/S00071536(81)80076-9. 
BÄRLOCHER, F. Water-borne conidia of aquatic hyphomycetes: seasonal and yearly patterns in Catamaran Brook, New Brunswick, Canada. Canadian Journal of Botany, 2000, 78(2), 157-167. http://dx.doi.org/10.1139/b99-172.

BÄRLOCHER, F., HELSON, J.E. and WILLIAMS, D.D. Aquatic hyphomycete communities across a land-use gradient of Panamanian streams. Fundamental and Applied Limnology, 2010, 177(3), 209-221. http://dx.doi.org/10.1127/18639135/2010/0177-0209.

BAUdoIN, J., GUEROLD, F., FELTEN, V., CHAUVET, E., WAGNER, P.Y. and ROUSSELLE, P. Elevated aluminium concentration in acidified headwater streams lowers aquatic hyphomycetes diversity and impairs leaf-litter breakdown. Microbial Ecology, 2008, 56(2), 260-269. http://dx.doi. org/10.1007/s00248-007-9344-9. PMid:18202885.

BELLIVEAU, M.J.R. and BÄRLOCHER, F. Molecular evidence confirms multiple origins of aquatic hyphomycetes. Mycological Research, 2005, 109(12), 1407-1417. http://dx.doi.org/10.1017/ S0953756205004119. PMid:16353640.

BRASIL. Ministério do Meio Ambiente - MMA. Conselho Nacional do Meio Ambiente-CONAMA. Resolução CONAMA no 357, de 17 de março de 2005. Diário Oficial da União [da] República Federativa do Brasil, Poder Executivo, Brasília, DF, 18 mar. 2005, no. 53, pp. 58-63.

BRASIL. Ministério do Meio Ambiente - MMA. Instituto Brasileiro do Meio Ambiente e Recursos Naturais Renováveis - IBAMA. 2006. Plano operativo de prevenção e combate aos incêndios florestais da Reserva Biológica da Pedra Talhada. Brasília.

BRASIL. Ministério da Saúde. Portaria no 2914, de 12 de dezembro de 2011. Dispóe sobre os procedimentos de controle e de vigilância da qualidade da água para consumo humano e seu padrão de potabilidade. Diário Oficial da Uniāo [da] República Federativa do Brasil, Poder Executivo, Brasília, DF, 14 dez. 2011, Seção 1, no. 239, pp. 39-46.

CASTAÑEDA-RUIZ, R.F., HEREDIA, G., GUSMÃO, L.F.P. and LI, D.-W. Fungal diversity of Central and South America In: D.-W. LI, ed. Biology of microfungi. Switzerland: Springer International Publishing, 2016, pp. 197-217. http://dx.doi.org/10.1007/978-3-31929137-6_9.

CAVALCANTI, M.S. and MILANEZ, A.I. Hyphomycetes from water and soil at the Dois Irmãos Forest Reserve, Recife, Pernambuco State, Brazil. Acta Botanica Brasílica, 2007, 21(4), 857-862. http:// dx.doi.org/10.1590/S0102-33062007000400010.

CHAMIER, A.-C. Water chemistry. In: F. BÄRLOCHER, ed. The ecology of aquatic hyphomycetes. Berlin: Springer, 1992, pp. 152-172. http://dx.doi. org/10.1007/978-3-642-76855-2_8.
CHAUVET, E. and SUBERKROPP, K. Temperature and sporulation of aquatic hyphomycetes. Applied and Environmental Microbiology, 1998, 64(4), 15221525. http://dx.doi.org/10.1128/AEM.64.4.15221525.1998. PMid:16349551.

CHAUVET, E. Aquatic hyphomycete distribution in South-Western France. Journal of Biogeography, 1991, 18(6), 699-706. http://dx.doi.org/10.2307/2845551.

CHAUVET, E., CORNUT, J., SRIDHAR, K.R., SELOSSE, M. and BÄRLOCHER, F. Beyond the water column: aquatic hyphomycetes outside their preferred habitat. Fungal Ecology, 2016, 19, 112-127. http://dx.doi.org/10.1016/j.funeco.2015.05.014.

CHENG, Z.L., ANDRE, P. and CHIANG, C. Hyphomycetes and macroinvertebrates colonizing leaf litter in two Belgian streams with contrasting water quality. Limnetica, 1997, 13, 57-63.

CZECZUGA, B., MAZALSKA, B., GODLEWSKA, A. and MUSZYŃSKA, E. Aquatic fungi growing on dead fragments of submerged plants. Limnologica, 2005, 35(4), 283-297. http://dx.doi.org/10.1016/j. limno.2005.07.002.

DANGER, M., GESSNER, M.O. and BÄRLOCHER, F. Ecological stoichiometry of aquatic fungi: current knowledge and perspectives. Fungal Ecology, 2016, 19, 100-111. http://dx.doi.org/10.1016/j. funeco.2015.09.004.

DESCALS, E. and MORALEJO, E. Water and asexual reproduction in the Ingoldian fungi. Botanica Complutensis, 2001, 25, 13-71.

DESCALS, E. Diagnostic characters of propagules of Ingoldian fungi. Mycological Research, 2005, 109(Pt 5), 545-555. http://dx.doi.org/10.1017/ S0953756205002728. PMid:16018309.

DUARTE, S., BÄRLOCHER, F., PASCOAL, C. and CASSIO, F. Biogeography of aquatic hyphomycetes: Current knowledge and future perspectives. Fungal Ecology, 2016, 19, 169-181. http://dx.doi. org/10.1016/j.funeco.2015.06.002.

DUARTE, S., PASCOAL, C., CÁSSIO, F. and BÄRLOCHER, F. Aquatic hyphomycete diversity and identity affect leaf litter decomposition in microcosms. Oecologia, 2006, 147(4), 658-666. http://dx.doi.org/10.1007/s00442-005-0300-4. PMid:16496184.

ELLIS, M.B. Dematiaceous Hyphomycetes. Kew: Commonwealth Mycological Institute, 1971.

ELLIS, M.B. More Dematiaceous Hyphomycetes. Kew: Commonwealth Mycological Institute, 1976.

FERNANDES, I., UZUN, B., PASCOAL, C. and CÁSSIO, F. Responses of aquatic fungal communities on leaf litter to temperature-change events. International Review of Hydrobiology, 2009, 94(4), 410-418. http://dx.doi.org/10.1002/ iroh.200811163. 
FERNÁNDEZ, R., VINCENZO, S. and SMITH, G. Evaluación de los hifomicetos acuáticos como bioindicadores de calidad ambiental en el río Chirgua (Bejuma, Venezuela). Gestion y Ambiente, 2017, 20(1), 82-94. http://dx.doi.org/10.15446/ ga.v20n1.62241.

FIUZA, P., PÉREZ, T.C., GULIZ, V. and GUSMÃO, L.F.P. Ingoldian fungi of Brazil: some new records and a review including a checklist and a key. Phytotaxa, 2017, 306(3), 171-200. http://dx.doi.org/10.11646/ phytotaxa.306.3.1.

FIUZA, P.O. and GUSMÃO, L.F.P. Ingoldian fungi from the semi-arid Caatinga biome of Brazil. Mycosphere, 2013, 4(6), 1133-1150. http://dx.doi.org/10.5943/ mycosphere/4/6/10.

FIUZA, P.O., COSTA, L.A., MEdEIROS, A.O., GULIS, V. and GUSMÃO, L.F.P. Diversity of freshwater hyphomycetes associated with leaf litter of Calophyllum brasiliense in streams of the semiarid region of Brazil. Mycological Progress, 2019, 18(7), 907-920. http://dx.doi.org/10.1007/s11557-01901501-6.

FIUZA, P.O., OTTONI-BOLDRINI, B.M.P., MONTEIRO, J.S., CATENA, N.R., HAMADA, N. and GUSMÃO, L.F.P. First records of Ingoldian fungi from the Brazilian Amazon. Brazilian Journal of Botany, 2015, 38(3), 615-621. http://dx.doi. org/10.1007/s40415-015-0157-7.

GARDNER, G. The challenge for Johannesburg: creating a more secure world. In: L. STARKE, ed. State of the world: a worldwatch institute report on progress toward a sustainable society. New York: W. W. Norton, 2002.

GOH, T.K. and HYDE, K.D. Biodiversity of freshwater fungi. Journal of Industrial Microbiology, 1996, 17(5-6), 328-345. http://dx.doi.org/10.1007/ BF01574764.

GONÇALVES JUNIOR, J.F., GRAÇA, M.A.S. and CALLISTO, M. Litter decomposition in a Cerrado savannah stream is retarded by leaf toughness, low dissolved nutrients and a low density of shredders. Freshwater Biology, 2007, 52(8), 1440-1451. http:// dx.doi.org/10.1111/j.1365-2427.2007.01769.x.

GOTElli, N.J. and ELliSON, A.M. Principios de estatistica em Ecologia. Porto Alegre: Artmed, 2011.

GRAÇA, M.A.S. Effects of water pollution on assemblages of aquatic fungi. Limnetica, 1994, 10(2), 41-43.

GRAÇA, M.A.S., HYDE, K. and CHAUVET, E. Aquatic hyphomycetes and litter decomposition in tropical - subtropical low order streams. Fungal Ecology, 2015, 19, 182-189. http://dx.doi.org/10.1016/j. funeco.2015.08.001.

GRATTAN II, R.M. and SUBERKROPP, K. Effects of nutrient enrichment on yellow poplar leaf decomposition and fungal activity in streams. Journal of the North American Benthological Society, 2001, 20(1), 33-43. http://dx.doi.org/10.2307/1468186.

GUIMARÃES, J.R. A., STUDER, A., TRIVELLATO, C. Educação ambiental no entorno da reserva biológica de Pedra Talhada. X Fórum Ambiental da Alta Paulista, 2014, 10(6), 32-45.

GULIS, V. and SUBERKROPP, K. Leaf litter decomposition and microbial activity in nutrientenriched and unaltered reaches of a headwater stream. Freshwater Biology, 2003, 48(1), 123-134. http:// dx.doi.org/10.1046/j.1365-2427.2003.00985.x.

HAIR JUNIOR, J.F., BLACK, W.C., BABIN, B.J., ANDERSON, R.E. and TATHAN, R.L. Análise multivariada de dados. 6. ed. Porto Alegre: Bookman, 2009.

INGOLD, C.T. An illustrated guide to aquatic and water-borne hyphomycetes (Fungi Imperfecti) with notes on their biology. Ambleside: Freshwater Biological Association, 1975. Scientific Publication, vol. 30.

INGOLD, C.T. The tetraradiate aquatic fungal spore. Mycologia, 1966, 58(1), 43-56. http://dx.doi. org/10.2307/3756987.

ITTNER, L.D., JUNGHANS, M. and WERNER, I. Aquatic fungi: a disregarded trophic level in ecological risk assessment of organic fungicides. Frontiers in Environmental Science, 2018, 6, 105. http://dx.doi. org/10.3389/fenvs.2018.00105.

JÖRDENING, H.J. and WINTER, J. Environmental biotechnology. Weinheim: Wiley-VCH Verlag GmbH \& Co. KGaA, 2005.

KRAUSE, L.M., FIUZA, P.O. and BARBOSA, F.R. Xylomyces (Aliquandostipitaceae, Jahnulales) freshwater hyphomycetes from the Brazilian Amazon. Nova Hedwigia, 2020, 111(1-2), 1-12. http://dx.doi. org/10.1127/nova_hedwigia/2020/0590.

KRAUSS, G., SRIDHAR, K.R., JUNG, K., WENNRICH, R., EHRMAN, J. and BÄRLOCHER, F. Aquatic Hyphomycetes in Polluted Groundwater Habitats of Central Germany. Microbial Ecology, 2003, 45(4), 329-339. PMid:12704555.

LIBÂNIO, M. Fundamentos de qualidade e tratamento de água. Campinas: Átomo, 2005.

LOMBARD, L., VAN DER MERWE, N.A., GROENEWALD, J.Z. and CROUS. P.W. Generic concepts in Nectriaceae. Studies in Mycology, 2015, 80, 189-245. http://dx.doi.org/10.1016/j. simyco.2014.12.002.

MACÊDO, J.A. Métodos laboratoriais de análise físicos quimicos e microbiológicos. 3. ed. Belo Horizonte: Jorge Macêdo, 2005.

MAGALHÃES, M.R.L. Concentraçóes naturais de elementos químicos da classe Insecta do fragmento florestal de Mata Atlantica reserva Charles Darwin [Dissertação de Mestrado em Tecnologias Energéticas e Nucleares]. Recufe: Universidade Federal de Pernambuco, 2015. 
MALOSSO, E. Hyphomycetes em ambientes aquáticos lótico e lêntico: ocorrência e biomassa [Dissertação de Mestrado em Ecologia e Recursos Naturais]. São Carlos: Universidade Federal de São Carlos, 1999.

MARVANOVÁ, L. Freshwater Hyphomycetes: a survey with remarks on tropical taxa. In: K.K. JANARDHANAN, C. RAJENDRAN, K. NATARAJAN and D. L. HAWSWORTH, eds. Tropical mycology. Enfield: Science Publishers, 1997, pp. 169-226.

MATSUSHIMA, T. Matsushima Mycological Memoirs. Published by the author. Kobe, 1985.

MEDEIROS, A.O., PASCOAL, C. and GRAÇA, M.A.S. Diversity and activity of aquatic fungi under low oxygen conditions. Freshwater Biology, 2009, 54(1), 142-149. http://dx.doi.org/10.1111/j.13652427.2008.02101.x.

MONTEIRO, J.S. and GUSMÃO, L.F.P. An emendation of Fusticeps and two new species from the Brazilian Amazon Forest. Mycotaxon, 2013, 123(1), 431-437. http://dx.doi.org/10.5248/123.431.

MOREIRA, C.G. and SCHOENLEIN-CRUSIUS, I.H. Nova espécie e novos registros para o Brasil de hifomicetos em folhedo submersos coletados no Parque Municipal Alfredo Volpi, São Paulo, SP, Brasil. Hoehnea, 2012, 39(4), 521-527. http://dx.doi. org/10.1590/S2236-89062012000400001.

MOREIRA, C.G. Sucessão de hifomicetos e avaliação da biomassa fúngica durante a decomposição de folhedo de Caesalpinia echinata Lam. e Campomanesia phaea (O. Berg.) Landrum submersos em lagos artificiais na cidade de São Paulo, SP [Tese de Doutorado em Biodiversidade Vegetal e Meio Ambiente]. São Paulo: Instituto de Botânica de São Paulo, 2011.

MORO, L.B. and SCHOENLEIN-CRUSIUS, I.H. Freshwater hyphomycetes in a preserved insular system from Brazil: first records at the Parque Estadual da Ilha do Cardoso, municipality of Cananéia, São Paulo State, Brazil. Hoehnea, 2020, 47, e832018. http://dx.doi.org/10.1590/22368906-83/2018.

MULHOLLAND, P.J., ELWOOD, J.W., NEWBOLD, J.D., WEBSTER, J.R., FERREN, L.A. and PERKINS, R.E. Phosphorus uptake by decomposing leaf detritus: effect of microbial biomass and activity. Internationale Vereinigung für Theoretische und Angewandte Limnologie: Verhandlungen, 1984, 22(3), 1899-1905. http://dx.doi.org/10.1080/03680770.1 983.11897591.

NILSSON, S. Freshwater hyphomycetes. Symbolae Botanicae Upsalienses, 1964, 18, 1-130.

OLIVEIRA, M.S. Micobiota em folhas submersas em dois mananciais sob proteção ambiental no estado de Pernambuco [Dissertação de Mestrado em Biologia de Fungos]. Recife: Universidade Federal de Pernambuco, 2016.
ORTIZ-VERA, M.P., OLCHANHESKI, L.R., SILVA, E.G., LIMA, F.R., MARTINEZ, L.R.P.R., SATO, M.I.Z., JAFFÉ, R., ALVES, R., ICHIWAKI, S., PADILLA, G. and ARAÚJO, W.L. Influence of water quality on diversity and composition of fungal communities in a tropical river. Scientific Reports, 2018, 8(1), 14799. http://dx.doi.org/10.1038/ s41598-018-33162-y. PMid:30287878.

PASCOAL, C., MARVANOVÁ, L. and CÁSSIO, F. Aquatic hyphomycete diversity in streams of Northwest Portugal. Fungal Diversity, 2005, 19, 109-128.

POHLING, R. Reaçôes químicas na análise de água. Fortaleza: Arte Visual Gráfica e Editora, 2009.

RAJASHEKHAR, M. and KAVERIAPPA, K.M. Diversity of aquatic hyphomycetes in the aquatic ecosystems of the Western Ghats of India. Hydrobiologia, 2003, 501(1-3), 167-177. http:// dx.doi.org/10.1023/A:1026239917232.

RASVAILER, V.S., SCOARIZE, M.M.R. and BENEDITO, E. Diversidade de fungos aquáticos em uma lagoa urbana da Mata Atlântica. Arquivos do Mudi, 2020, 24(2), 84-97. http://dx.doi. org/10.4025/arqmudi.v24i2.52474.

ROSEMOND, A.D., PRINGLE, C.M., RAMÍREZ, A., MICHAEL, J.P. and JUDY, L.M. Landscape variation in phosphorus concentration and effects on detritus-based tropical streams. Limnology and Oceanography, 2002, 47(1), 278-289. http://dx.doi. org/10.4319/lo.2002.47.1.0278.

ROSSMAN, A.Y., ALLEN, W.C., BRAUN, U., CASTLEBURY, L.A., CHAVERRI, P., CROUS, P.W., HAWKSWORTH, D.L., HYDE, K.D., JOHNSTON, P., LOMBARD, L., ROMBERG, M., SAMSON, R.A., SEIFERT, K.A., JEFFREY, K.S., UDAYANGA, D. and WHITE, J.F. Overlooked competing asexual and sexually typified generic names of Ascomycota with recommendations for their use or protection. IMA Fungus, 2016, 7(2), 289-308. http:// dx.doi.org/10.5598/imafungus.2016.07.02.09.

SALES, M.A., GONÇALVES JÚNIOR, J.F., DAHORA, J.S. and MEDEIROS, A.O. Influence of leaf quality in microbial decomposition in a headwater stream in the Brazilian Cerrado: a 1-year study. Microbial Ecology, 2015, 69(1), 84-94. http://dx.doi.org/10.1007/s00248-014-0467-5. PMid:25096988.

SANTIAGO, A.C.P. and BARROS, I.C.L. Pteridoflora do Refúgio Ecológico Charles Darwin (Igarassu, Pernambuco, Brasil). Acta Botanica Brasílica, 2003, 17(4), 597-604. http://dx.doi.org/10.1590/S010233062003000400011.

SCHOENLEIN-CRUSIUS, I.H. and GRANDI, R.A.P. A diversidade dos Hyphomycetes aquáticos nas águas continentais da América do Sul. Brazilian Journal of Microbiology, 2003, 34(3), 183-193. 
SCHOENLEIN-CRUSIUS, I.H. and MILANEZ, A.I. Sucessão fúngica em folhas de Ficus microcarpa Lf submersas no lago frontal situado no Parque Estadual das Fontes do Ipiranga, São Paulo, SP. Revista de Microbiologia, 1989, 32(3), 411-426.

SCHOENLEIN-CRUSIUS, I.H. Aquatic hyphomycetes from Cerrado regions in the state of São Paulo, Brazil. Mycotaxon, 2002, 81, 457-462.

SCHOENLEIN-CRUSIUS, I.H., DINIZ, B.F., COSTA, R.T., SABINO, A.P.R., MORO, L.B., BORO, M., ISHIDA, C.M., JESUS, A.L. and PIRES-ZOTTARELLI, C.L.A. Diversity of conidial fungi and some abiotic variables of the water after the reopening of the Pirarungaua stream in the Jardim Botânico, São Paulo, São Paulo State, Brazil. Hoehnea, 2016, 43(1), 57-75. http://dx.doi. org/10.1590/2236-8906-58/2015.

SCHOENLEIN-CRUSIUS, I.H., MOREIRA, C.G. and BICUDO, D.C. Aquatic Hyphomycetes in the Parque Estadual das Fontes do Ipiranga - PEFI, São Paulo, Brazil. Brazilian Journal of Botany, 2009, 32(3), 411-426. http://dx.doi.org/10.1590/S010084042009000300003 .

SCHOENLEIN-CRUSIUS, I.H., MOREIRA, C.G. and GOMES, E.P.C. Riqueza dos fungos ingoldianos e dos fungos aquáticos facultativos do Parque Municipal da Aclimação, São Paulo, SP, Brasil. Hoehnea, 2015, 42(2), 239-251. http://dx.doi. org/10.1590/2236-8906-52/2014.

SCHOENLEIN-CRUSIUS, I.H., MOREIRA, C.G. and GOMES, E.P.C. Riqueza de fungos ingoldianos e de fungos aquático-facultativos no Parque Municipal do Carmo, São Paulo, SP, Brasil. Hoehnea, 2018, 45(3), 379. http://dx.doi.org/10.1590/2236-8906$24 / 2018$.

SCHOENLEIN-CRUSIUS, I.H., MOREIRA, C.G., TAKAHASHI, J.P. and GOMES, E.P.C. Riqueza dos fungos ingoldianos e aquáticos facultativos no Parque Municipal do Ibirapuera, Sáo Paulo, SP, Brasil. Hoehnea, 2014, 41(1), 61-76. http://dx.doi. org/10.1590/S2236-89062014000100006.

SCOARIZE, M.M.R. Distribuição e diversidade de hifomicetos aquáticos em riachos Neotropicais [Dissertação de Mestrado em Ecologia de Ambientes Aquáticos Continentais]. Maringá: Universidade Estadual de Maringá, 2018.

SEIFERT, K., MORGAN-JONES, G., GAMS, W. and KENDRICK, B. The genera of Hyphomycetes. Utrecht: CBS-KNAW Fungal Biodiversity Centre, 2011. CBS Biodiversity Series, no. 9.

SEKERKA, I. and LECHNER, J.F. Determination of alkalinity and acidity of water by conductometric acid-base titration. Journal - Association of Official Analytical Chemists, 1984, 67(5), 893-895. http:// dx.doi.org/10.1093/jaoac/67.5.893.
SHEARER, C.A., DESCALS, E., KOHLMEYER, B., KOHLMEYER, J., MARVANOVÁ, L., PADGETT, D., PORTER, D., RAJA, H.A., SCHMIT, J.P., THORTON, H.A. and VOGLYMAYR, H. Fungal biodiversity in aquatic habitats. Biodiversity and Conservation, 2007, 16(1), 49-67. http://dx.doi. org/10.1007/s10531-006-9120-z.

SILVA, G.V.R., CASTAÑEDA-RUIZ, R.F. and MALOSSO, E. Comparison of aquatic hyphomycetes communities between lotic and lentic environments in the Atlantic rain forest of Pernambuco, Northeast Brazil. Fungal Biology, 2019, 123(9), 660-668. http://dx.doi.org/10.1016/j.funbio.2019.05.013. PMid:31416585.

SRIDHAR, K.R. and BÄRLOCHER, F. Initial colonization, nutrient supply, and fungal activity on leaves decaying in streams. Applied and Environmental Microbiology, 2000, 66(3), 1114-1119. http:// dx.doi.org/10.1128/AEM.66.3.1114-1119.2000. PMid:10698779.

SRIDHAR, K.R. and RAVIRAJA, N.S. Aquatic hyphomycetes and leaf litter processing in unpolluted and polluted habitats. In: J.K. MISRA and B.W. HORN, eds. Trichomycetes and other fungal groups. Enfield: Science Publishers, 2001. http://dx.doi. org/10.13140/RG.2.1.3809.9602.

SRIDHAR, K.R., ARUN, A.B., MARIA, G.L. and MADHYASATHA, M.N. Diversity of fungi on submerged leaf and woody litter in river Kali, Southwest India. Environmental Research Journal, 2011, 5, 701-714.

SUBERKROPP, K. and CHAUVET, E. Regulation of Leaf breakdown by fungi in streams: influences of water chemistry. Ecology, 1995, 76(5), 1433-1445. http://dx.doi.org/10.2307/1938146.

SUBERKROPP, K. Interactions with invertebrates. In: F. BÄRLOCHER, ed. The ecology of aquatic hyphomycetes. Berlin: Springer-Verlag, 1992, pp. 118-134. http://dx.doi.org/10.1007/978-3-64276855-2_6.

SURESHA, H.R., KRISHNAPPA, M., DESCALS, E., RAJU, G.H. and TAYLOR, B.R. Diversity of aquatic hyphomycetes in Kalathgiri Falls of Chikmagalur District, Karnataka, India. International Journal of Microbiology Research, 2013, 5(3), 410-416. http:// dx.doi.org/10.9735/0975-5276.5.3.410-416.

SUZUKI, S. and NIMURA, H. Relation between the distribution of aquatic hyphomycetes in Japanese lakes and lake types. Botanical Magazine Tokyo, 1961, 74(872), 51-55. http://dx.doi.org/10.15281/ jplantres1887.74.51.

SUZUKI, S. and NIMURA, H. The microbiological studies of the lakes of Volcano Bandai II. Ecological study on aquatic hyphomycetes in the Goshikinuma and Akanuma Lake group. Botanical Magazine Tokyo, 1960, 73(867), 360-364. http://dx.doi. org/10.15281/jplantres1887.73.360. 
WEISS, C.H. StatSoft, Inc., Tulsa, O.K. STATISTICA, Version 8.0. AStA Advances in Statistical Analysis, 2007, 91(3), 339-341. http://dx.doi.org/10.1007/ s10182-007-0038-x.

WONG, M.K.M., GOH, T.-K., HODGKISS, I.J., HYDE, K.D., RANGHOO, V.M., TSUI, C.K.M., HO, W.-H., WONG, W.S.W. and YUEN, T.-K. Role of fungi in freshwater ecosystems. Biodiversity and Conservation, 1998, 7(9), 1187-1206. http:// dx.doi.org/10.1023/A:1008883716975.

WOOD-EGGENSCHWILER, S. and BÄRLOCHER, F. Geographical distribution of Ingoldian fungi. Internationale Vereinigung für Theoretische und
Angewandte Limnologie: Verhandlungen, 1985, 22, 2780-2785.

ZHANG, Y., GUO, L.D. and LIU, R.J. Survey of arbuscular mycorrhizal fungi in deforested and natural forest land in the subtropical region of Dujiangyan, Southwest China. Plant and Soil, 2004, 261(1-2), 257-263. http://dx.doi.org/10.1023/ B:PLSO.0000035572.15098.f6.

Received: 19 February 2021 Accepted: 01 November 2021

Associate Editor: André Megali Amado. 